\title{
What Do Matter Entrepreneurial Competencies on Business Performance? An Empirical Investigation of SMEs in Indonesia
}

\author{
Yudha Prakasa* \\ Department of Business Administration \\ Universitas Brawijaya \\ Malang, Indonesia \\ *y.prakasa87@ub.ac.id
}

\begin{abstract}
This study aims to examine the relationship between entrepreneurial competence and business performance in SMEs, which contributes to SMEs' development by strengthening entrepreneurial competencies. This research object is the owner of Batik SMEs in Bayat Klaten, Central Java, Indonesia. This study uses a quantitative approach to investigate whether entrepreneurial competence has a significant effect on business performance by involving 138 owners of Batik SMEs as respondents. The sampling technique used proportional random sampling and the hypothesis were tested using structural equation modelling of least squares, adopting the SmartPLS software. The results showed that Entrepreneurial Competencies have a positive and significant effect on Business Performance. It means that the higher the Entrepreneurial Competencies, the more potential it will increase business performance. Leadership Competency and Innovation Competency have the largest contribution in forming Entrepreneurial Competencies for SMEs in enhancing their business performance. Furthermore, RiskTaking Competency has the lowest contribution in establishing Entrepreneurial Competencies. Indeed, it makes a challenge for SMEs in an uncertainty business era.
\end{abstract}

Keywords-SMEs, entrepreneurial competencies, business performance

\section{INTRODUCTION}

Micro, Small and Medium Enterprises (MSMEs) are recognized as business entities that have a vital role in economic development and growth in developing and developed countries. For Indonesia, MSMEs are the largest business sector (99\%) and can contribute to job creation by $89 \%$. However, GDP contribution is still $60 \%$, smaller than Large Enterprises, which only amount to $1 \%$ of all existing business entities [1]. The competitiveness of Indonesian MSMEs at the ASEAN level is still low compared to Singapore, Malaysia and Thailand [2]. The government role in improving entrepreneurial skills also needs to be enhanced sustainability as has been done by Singapore, Thailand, Malaysia and Philippine [2]. SMEs success factors such as managerial capacity and leadership [3] are still a challenge for SMEs in Indonesia. Previous studies stated that the factors that determine SMEs ability to innovate include entrepreneurial creativity and entrepreneurial competencies [4].

Entrepreneurial competencies are critical to measuring business success. The knowledge possessed by an entrepreneur in running his business can be seen from making decisions by looking at the good and bad impacts of the decisions taken. It means that entrepreneurs (especially SMEs) are the main drivers of the company internal resources to achieve business success [5]. Competencies possessed by an entrepreneur can minimize the negative impact of a dynamic business environment. Entrepreneurial competencies are proven to have a significant contribution to improving SMEs performance [6,7]. Entrepreneurial skills, market orientation and sales, networking are also proven to strengthen entrepreneurial competencies [6].

Central Java Province is one of the centres for Batik SMEs in Indonesia. As is well known, Batik is an authentic Indonesian culture and an industry capable of absorbing labour [8]. Since UNESCO designated it as a world cultural heritage owned by Indonesia, the demand for Batik has also increased. The Ministry of Industry noted that Indonesia batik exports reached the US \$ 52.4 million or around Rp. 747.4 billion in 2018. Meanwhile, the export value of woven fabrics only reached the US \$ 976 thousand or around Rp. 13.91 billion. From these data, it can be seen that the demand for Batik is very high.

One of the Batik Industrial Centers in Central Java is Bayat District, Klaten Regency, which has 209 batik entrepreneurs. Batik Bayat Centre is famous for hand-written Batik, which is still manual production, so it really depends on skills and experience. It has become potential in the handicraft industry. Some of the problems that occur, as stated by Sarwadi (Chairman of the Written Batik Group in the village of Jarum) are (1) the limited knowledge of Batik MSME to export their products considering that the price of hand-written Batik is relatively high when marketed in the domestic market, (2) limited knowledge to produce innovative products, (3) courage to take orders in large numbers from consumers, and (4) regeneration of hand-written Batik who are increasingly 
demanding. Even so, the industrial of hand-written Batik in Bayat has survived for 25 years. This phenomenon is interesting to study. This study aims to examine whether entrepreneurial competencies significantly affect business performance in the MSME sector.

\section{RELATED WORK}

Entrepreneurial Competencies (EC) consist of components that are very inherent in a person (personality, attitudes, traits, social roles and self-image) as well as skills, knowledge and experiences that can be learned in the workplace or through education and training [9]. It illustrates the company internal resources as capital to increase competitive advantage as the Resource-Based View (RBV) concept. According to RBV, a company able to create value will depend on the company ability to acquire and develop its resources [6]. It means that EC will significantly affect its ability to improve its business performance to be competitive. Some researchers have defined EC into three perspectives: cognitive competence (work-related knowledge and understanding), behavioural competence (knowing how to behave) and functional competence (workrelated knowledge, skills) [7]. These three perspectives are very relevant to the RBV concept used in this study. SMEs willing to improve their entrepreneurial skills with adequate competencies will have more ability to manage companies in an uncertain business environment [7].

Competence is a comprehensive concept consisting of a collection of ideas that help a person transmit his ideas into reality [10]. Whereas in entrepreneurship, competence is closely related to the ability to manage a company from the start-up, growth, to sustainability levels [6]. Business continuity, including MSMEs, can be obtained if the company can maintain and improve its business performance.

Previous research has proven that entrepreneurial competencies have been shown to positively and significantly affect MSME business performance [6,7,11]. Furthermore, innovation competency, leadership competency, networking competency, and risk-taking competency can strengthen entrepreneurial competency so that they positively impact SMEs' performance [11]. Based on the theory and existing empirical evidence, this study proposed the hypothesis as follows and the research theoretical model show in figure 1.

H1. Entrepreneurial Competencies have a positive influence on SMEs Business Performance.

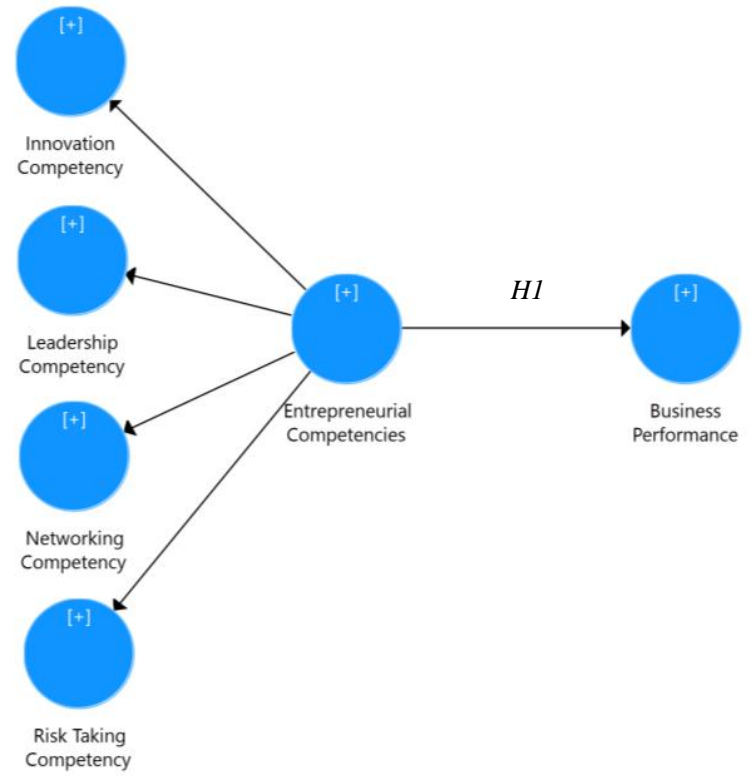

Fig. 1. Research theoretical model.

\section{MethodOLOGY}

This type of research is explanatory research with a quantitative approach. The study was conducted at Batik Industrial Center, Klaten, Central Java involving 138 SMEs as a respondent. The number of respondents was taken using the Slovin formula with an allowance level of 5\% of 209 people. The sampling technique used probability sampling with proportional random sampling, which is distributed proportionally to 5 villages in Bayat District. Measurement scale using the Likert scale with the scale of point 1 (strongly disagree) to score 5 (strongly agree) to measure respondents' answers. The instrument measurement was carried out with a validity and reliability test. Data analysis used SPSS software as a statistical tool to describe respondents' profiles and descriptive analysis. Furthermore, path analysis to test hypotheses used SmartPLS

Variable entrepreneurial competencies is a latent variable of second order. There are four dimensions of entrepreneurial competencies used in this study, as developed by Abdul [11]. The four dimensions are reflective construct that explains the entrepreneurial competencies, which are measured by 19 items, namely (1) Innovation Competency (IC) which includes innovation and renewal of ideas, business processes, markets, and products and services; (2) Leadership Competency (LC), which consists of the ability to influence employees, command and control, motivation, receive criticism and suggestions, role models, and clarity of business objectives; (3) Networking Competency (NC) which includes contacts and relations, alliance strategies, resource sharing, market transactions; and (4) Risk-Taking Competency (RTC) which provides for calculations in every decision, careful analysis, wise decisions, and taking risks that can be handled. While business performance, as a dependent variable of the first order, 
measurement in this study described the three dimensions of business performance: economic, environment, and social performance, which have 16 items developed by Prakasa [12].

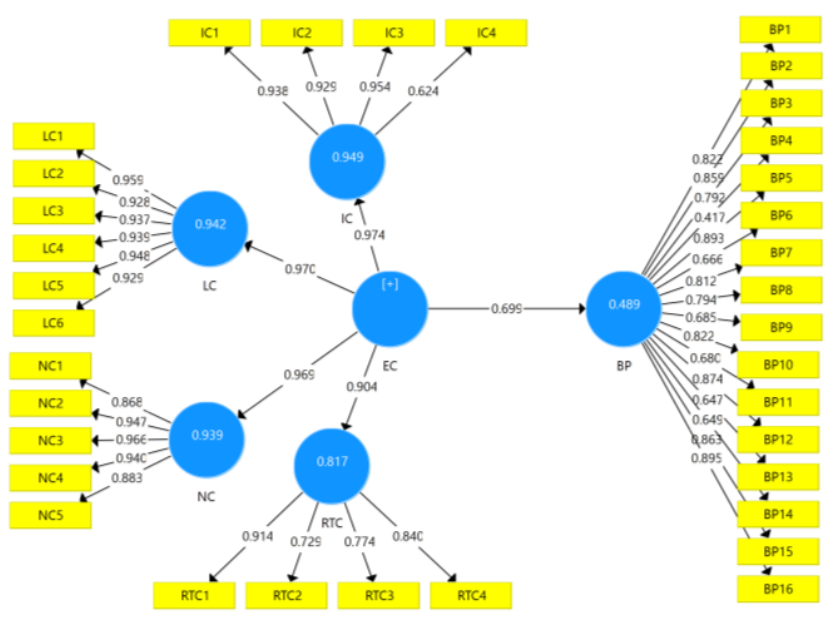

Fig. 2. Outer loading result.

The model evaluation (see Figure 2) shows that all outer loading values on each item in the entrepreneurial competencies variable as a reflective model have met all the minimum values, namely more than 0.5 . In the business performance construct, there is an outer loading value of less than 0.5 , namely BP4. The SEM method's basic principle is that if an outer loading value is $<0.5$, then the item must be eliminated [13]. Therefore, BP4 was omitted to improve model fit. After removing BP4 from the final model, it was proven that all outer loading values were satisfactory, including Composite Reliability (CR) and Average Variance Extracted (AVE) values were satisfied which were more than 0.6 and 0.5 (see Table 1).

Furthermore, the $R^{2}$ measurement of IC, LC, NC, and RTC, which has a value of more than 0.67 indicates that this dimension has substantially reflected the construct's entrepreneurial competence. These results provide practical implications in determining the MSME Batik development strategy in Bayat.
TABLE I. RESULT OF REFLECTIVE MODEL

\begin{tabular}{|c|c|c|c|c|c|}
\hline Construct & Indicator & Loading & $\mathbf{R}^{2}$ & CR & AVE \\
\hline \multicolumn{6}{|c|}{ Entrepreneurial Competencies (2nd order) } \\
\hline $\begin{array}{l}\text { Innovation } \\
\text { Capability }\end{array}$ & $\begin{array}{l}\text { IC1 } \\
\text { IC2 } \\
\text { IC3 } \\
\text { IC4 }\end{array}$ & $\begin{array}{l}0,938 \\
0,929 \\
0,954 \\
0,624\end{array}$ & 0,949 & 0,925 & 0,760 \\
\hline $\begin{array}{l}\text { Leadership } \\
\text { Capability }\end{array}$ & $\begin{array}{l}\text { LC1 } \\
\text { LC2 } \\
\text { LC3 } \\
\text { LC4 } \\
\text { LC5 } \\
\text { LC6 }\end{array}$ & $\begin{array}{l}0,959 \\
0,928 \\
0,937 \\
0,939 \\
0,948 \\
0,929\end{array}$ & 0,942 & 0,978 & 0,883 \\
\hline $\begin{array}{c}\text { Networking } \\
\text { Capability }\end{array}$ & $\begin{array}{l}\text { NC1 } \\
\text { NC2 } \\
\text { NC3 } \\
\text { NC4 } \\
\text { NC5 }\end{array}$ & $\begin{array}{l}0,868 \\
0,947 \\
0,966 \\
0,940 \\
0,883\end{array}$ & 0,939 & 0,966 & 0,849 \\
\hline $\begin{array}{l}\text { Risk-Taking } \\
\text { Capability }\end{array}$ & $\begin{array}{l}\text { RTC1 } \\
\text { RTC2 } \\
\text { RTC3 } \\
\text { RTC4 }\end{array}$ & $\begin{array}{l}0,914 \\
0,729 \\
0,774 \\
0,840\end{array}$ & 0,817 & 0,889 & 0,668 \\
\hline \multicolumn{6}{|c|}{ Business Performance (1 st order) } \\
\hline $\begin{array}{l}\text { Business } \\
\text { Performance }\end{array}$ & $\begin{array}{l}\text { BP1 } \\
\text { BP2 } \\
\text { BP3 } \\
\text { BP5 } \\
\text { BP6 } \\
\text { BP7 } \\
\text { BP8 } \\
\text { BP9 } \\
\text { BP10 } \\
\text { BP11 } \\
\text { BP12 } \\
\text { BP13 } \\
\text { BP14 } \\
\text { BP15 } \\
\text { BP16 }\end{array}$ & $\begin{array}{l}0,823 \\
0,859 \\
0,792 \\
0,893 \\
0,666 \\
0,812 \\
0,794 \\
0,685 \\
0,822 \\
0,680 \\
0,874 \\
0,647 \\
0,649 \\
0,863 \\
0,895\end{array}$ & 0,490 & 0,961 & 0,623 \\
\hline
\end{tabular}

\section{RESULTS AND DISCUSSION}

\section{A. Characteristics of Respondents}

Based on the tabulation of data from questionnaires spread to all respondents, respondent characteristics are presented in full through Table 2 . 
TABLE II. PROFILE OF RESPONDENTS

\begin{tabular}{|c|c|c|c|}
\hline Criteria & Categories & $\begin{array}{c}\text { Frequenc } \\
\mathbf{y}\end{array}$ & $\begin{array}{c}\text { Percentage } \\
(\%)\end{array}$ \\
\hline \multirow[t]{2}{*}{ Gender } & Male & 13 & 9,4 \\
\hline & Female & 125 & 90,6 \\
\hline \multirow[t]{8}{*}{ Age } & $25-30$ & 9 & 6,5 \\
\hline & $31-36$ & 9 & 6,5 \\
\hline & $37-42$ & 27 & 19,6 \\
\hline & $43-47$ & 29 & 21,1 \\
\hline & $48-52$ & 25 & 18,1 \\
\hline & $53-57$ & 25 & 18,1 \\
\hline & $58-62$ & 12 & 8,7 \\
\hline & $>63$ & 2 & 1,4 \\
\hline \multirow{4}{*}{$\begin{array}{c}\text { Education } \\
\text { Level }\end{array}$} & Elementary School & 73 & 52,9 \\
\hline & Junior High School & 36 & 26,1 \\
\hline & Senior High School & 25 & 18,1 \\
\hline & Undergraduate & 4 & 2,9 \\
\hline \multirow{8}{*}{$\begin{array}{l}\text { Seniority of the } \\
\text { business (year) }\end{array}$} & $2-5$ & 17 & 12,3 \\
\hline & $6-9$ & 7 & 5 \\
\hline & $10-13$ & 101 & 73 \\
\hline & $14-17$ & 5 & 3,8 \\
\hline & $18-21$ & 5 & 3,8 \\
\hline & $22-25$ & 2 & 1,4 \\
\hline & $26-29$ & - & - \\
\hline & $>30$ & 1 & 0,7 \\
\hline \multirow{8}{*}{$\begin{array}{l}\text { Total of } \\
\text { Employees }\end{array}$} & $2-4$ & 86 & 62,4 \\
\hline & $5-7$ & 26 & 18,8 \\
\hline & $8-10$ & 11 & 7,9 \\
\hline & $11-13$ & 1 & 0,8 \\
\hline & $14-16$ & 1 & 0,8 \\
\hline & $17-19$ & 1 & 0,8 \\
\hline & $20-22$ & 10 & 7 \\
\hline & $>23$ & 2 & 1,5 \\
\hline
\end{tabular}

Table 2 shows that $90,6 \%$ of respondents were female, the average age of 43 to 47 . It means that The MSME of HandWritten Batik is dominated by the baby boomer generation and $\mathrm{X}$ who are less adaptive in keeping up with technological developments. While referring to educational background, $52,9 \%$ of respondents have an elementary school educational background. It shows the limited knowledge possessed by respondents. However, 73\% of respondents had 10-13 years of work experience. It is the strength why the batik industry can still survive today. Meanwhile, if viewed from the number of employees, most of the respondents $(62.4 \%)$ were included in the micro business category, namely at most five employees. Others are the category of small and medium enterprises

\section{B. Descriptive Statistics}

The entrepreneurial competencies variable consists of 19 statements which are reflected into innovation capacity (4 statements), leadership capacity (6 statements), networking capacity ( 5 statement), and risk-taking capacity (4 statements). The Grand Mean score obtained from the entrepreneurial competencies variable is 3,8 in the good category. It means that respondents have felt good entrepreneurial competencies. Leadership Competency Indicator $(4,00)$ has the highest mean score, followed by Networking Capacity (3.8), Innovation Capacity (3.6), and Risk-Taking Capacity (3.5).
Business Performance variables consist of 16 statements. The highest score items are "the batik business activities that I have been doing have provided welfare for my family" and me with a mean score of 3.58. This statement shows the economic impact of the batik business activity. Furthermore, the highest item score $(4,7)$, indicating social performance is the statement "My batik business activity does not cause air pollution". It shows the high commitment of SMEs to preserve the environment. Besides, batik products with natural ingredients also contribute to reducing the environmental pollution. The challenge for Batik SMEs is the ability to recycle the waste generated during the production process. It indeed requires good innovation capabilities. The other hand, the statement "If there are complaints from customers, I can accept gracefully and respond quickly to their complaints" obtained the highest score of respondents' perceptions of business performance from a social perspective with a score of 4.8 (very high category).

\section{Structural Model Result}

Based on the bootstrapping results, it can be concluded that entrepreneurial competencies are proven to have a positive and significant effect on business performance with a statistical $\mathrm{T}$ value of 7,288 (see Figure 3 and Table 3). Its value is greater than 1.96, which is the minimum limit of a path coefficient which is declared significant; this is reinforced by a p-value of 0.000. These results support previous research which states that the performance of SMEs can be influenced by entrepreneurial competencies possessed by SMEs $[6,7,11]$.

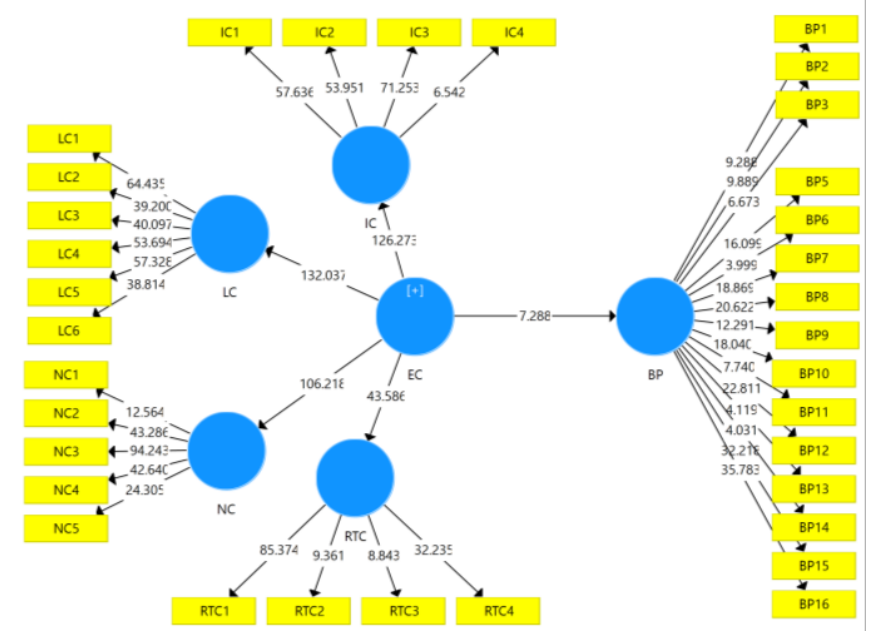

Fig. 3. Adjusted path model.

Furthermore, leadership competency is proven to have the most significant effect on entrepreneurial competence. It shows that one of the factors causing Batik industry in Bayat to survive is SMEs' experience, which is also reinforced by the score of respondents' perceptions of leadership competencies that get the highest mean score. The length of time that a business of Batik was established also contributed to building leadership competencies. Strong leadership will significantly determine the success of SMEs [3]. Meanwhile, risk-taking competency has the lowest influence in forming entrepreneurial 
competencies. It is reasonable considering the education level of respondents who are mostly at the elementary school level. At the same time, risk-taking competency relates to the ability to comprehensively analyze various things before making decisions, both from the perspective of the internal and external environment.

TABLE III. PATH COEFFICIENTS MODEL

\begin{tabular}{|l|l|l|}
\hline \multicolumn{1}{|c|}{ Relation } & \multicolumn{1}{|c|}{$\begin{array}{c}\text { T Statistics } \\
(\mid \mathbf{O} / \text { STDEV } \mid)\end{array}$} & $\boldsymbol{P}$ Values \\
\hline $\mathrm{EC} \rightarrow \mathrm{IC}$ & 126,273 & 0,000 \\
\hline $\mathrm{EC} \rightarrow \mathrm{LC}$ & 132,037 & 0,000 \\
\hline $\mathrm{EC} \rightarrow \mathrm{NC}$ & 106,218 & 0,000 \\
\hline $\mathrm{EC} \rightarrow \mathrm{RTC}$ & 43,586 & 0,000 \\
\hline $\mathrm{EC} \rightarrow \mathrm{BP}$ (Hypothesis $)$ & 7,288 & 0,000 \\
\hline
\end{tabular}

The empirical investigation suggests that the government can strengthen SMEs' entrepreneurial competencies by strengthening innovation competency and network competency. Innovation competency can be carried out through training and mentoring on business processes and innovative products. In contrast, network competency can be carried out by facilitating SMEs to access international markets. These two things, if carried out sustainably, will gradually increase risktaking competency. To improve business performance, the government can also re-popularize Batik to the younger generation. Batik, especially Hand-Written Batik, as a world heritage can be maintained and even improved. Batik industrial centres can also be developed as a tourism village with educational and heritage tourism.

\section{CONCLUSION AND Future SCOPE}

This research was conducted to determine and analyze the effect of Entrepreneurial Competencies on Business Performance. The results show that Entrepreneurial Competencies have a significant impact on Business Performance. Leadership competency has the greatest influence on SMEs Entrepreneurial Competence, continued with innovation competency, networking competency, and the lowest is risk-taking competency.

Future research is expected to develop entrepreneurial competency variables from different perspectives. Adding other variables, such as government policies (external perspective) and entrepreneurial motivation (internal perspective), as well as issues related to digital competency, will enrich knowledge on efforts to improve MSME business performance. It is crucial to help MSMEs become more competitive.

\section{ACKNOWLEDGMENT}

This research was supported by The Research and Community Services Board (BPPM) - Faculty of Administrative Science, Universitas Brawijaya. Special thanks to all Business Research and Development Center (K2PU) FIA UB teams who helped complete this research.

\section{REFERENCES}

[1] Asia Pacific Foundation of Canada, "Survey of entrepreneurs and MSMEs in Indonesia: Building the capacity of MSMEs through human capital." 2018.

[2] OECD/ERIA, "SME Policy Index. ASEAN 2018: Boosting Competitiveness and Inclusive Growth." 2018.

[3] T. Garavan, S. Watson, R. Carbery, and F. O'Brien, "The antecedents of leadership development practices in SMEs: The influence of HRM strategy and practice," Int. Small Bus. J., vol. 34, no. 6, pp. 870-890, 2016.

[4] Y. Shahid, "From Creativity to Innovation" Policy Research Working Paper 4262, June,” Dev. Res. Gr., 2007.

[5] N.H. Ahmad, T. Ramayah, C. Wilson, and L. Kummerow, "Is entrepreneurial competency and business success relationship contingent upon business environment? A study of Malaysian SMEs," Int. J. Entrep. Behav. Res., 2010.

[6] A. Al Mamun, S. A. Fazal, and R. Muniady, "Entrepreneurial knowledge, skills, competencies and performance: A study of microenterprises in Kelantan, Malaysia,” Asia Pacific J. Innov. Entrep., 2019.

[7] L. F. A, O. O. Iyiola, O. A. Adegbuyi, O. O. Ogunnaike, and A. A. Taiwo, "Modelling the relationship between entrepreneurial climate and venture performance: The moderating role of entrepreneurial competencies," Acad. Entrep. J., vol. 24, no. 1, pp. 1-16, 2018.

[8] W. Steelyana, "Batik, a beautiful cultural heritage that preserve culture and support economic development in Indonesia," Binus Bus. Rev., vol. 3, no. 1, p. 116, 2012.

[9] T.W.Y. Man, T. Lau, and K. F. Chan, "The competitiveness of small and medium enterprises: A conceptualization with focus on entrepreneurial competencies," J. Bus. Ventur., vol. 17, no. 2, pp. 123-142, 2002.

[10] N. Lazar and G. Paul, "Entrepreneurial competencies in a business enterprise-An overview," Int. J. Sci. Res., vol. 4, no. 1, pp. 226-227, 2015 .

[11] R.O. Abdul, "Effect of entrepreneurial competencies on the survival of small and medium enterprises in Kenya." JKUAT-COHRED, 2019.

[12] P. Yudha, "Exploring The Impact Of Social Capital On Entrepreneurial Orientation And Business Performance (Study On Members of MSMEs Communities in Malang)," PROFIT J. Adm. BISNIS, vol. 12, no. 1, pp. 20-31, 2019.

[13] J. F. Hair Jr, G. T. M. Hult, C. Ringle, and M. Sarstedt, A primer on partial least squares structural equation modeling (PLS-SEM). Sage publications, 2016. 